\title{
A novel protocol for mapping the spatial distribution of storm derived sediment in lakes
}

\author{
R. Timothy Patterson ${ }^{1}$ (D) - Veronica Mazzella ${ }^{1}$ Andrew L. Macumber ${ }^{1} \cdot$ Braden R. B. Gregory $^{1} \cdot$ Calder W. Patterson $^{2}$. \\ Nawaf A. Nasser ${ }^{1} \cdot$ Helen M. Roe ${ }^{3}$ Jennifer M. Galloway ${ }^{4} \cdot$ Eduard G. Reinhardt $^{5}$
}

Received: 31 July 2020 / Accepted: 18 November 2020 / Published online: 1 December 2020

(c) Springer Nature Switzerland AG 2020

\begin{abstract}
A novel geomatics methodology is presented for locating optimal lake coring sites to potentially capture evidence of paleo-storms. One hundred sediment-water interface samples collected from Harvey Lake, NB, Canada $\left(45^{\circ} 43^{\prime} 45^{\prime \prime} \mathrm{N}\right.$; $67^{\circ} 00^{\prime} 25^{\prime \prime} \mathrm{W}$ ) were analyzed using: end member mixing analysis (EMMA), which can be used to recognize modal grain size distributions derived from sediment resuspension during major storms; and Itrax X-ray fluorescence core scanningderived Ti, an indicator of catchment runoff, which is enhanced during major storm events. Simple geospatial models based on lake bathymetric and historical wind speed data (Fredericton INTL A climatological station; 1953-2015) were used to determine lake bottom areas susceptible to wave base sediment resuspension. EMMA End Member (EM) 02 ( mode $=40 \mu \mathrm{m}$ ) was widely distributed in areas $>4.4 \mathrm{~m}$ water depth, which have been unimpacted by wave base remobilization since 1953. Deposition of EM 02 in deeper water areas was interpreted to be of major storm derivation, the result of fallout of resuspended sediments from the water column. This EM was most concentrated in the central part of the lake at $>6 \mathrm{~m}$ water depth, as well as at the z-max $(\sim 11 \mathrm{~m})$, and in Herbert's Cove (3-6 m). The main source of run-off derived Ti into the lake was through Sucker Brook, with the highest concentrations in Herbert's Cove and the central part of the lake, including the lake z-max. This assessment indicates that the best undisturbed sedimentary record of paleo-storms is mostly likely in the central part of the lake north of the z-max at water depths of $>6 \mathrm{~m}$, as well as deeper water areas of Herbert's Cove.
\end{abstract}

Keywords Storm wave base · Sediment resuspension · End member mixing analysis (EMMA) - Itrax XRF-CS · Geomatics · New Brunswick, Canada

\section{Introduction}

Lake sediments archive various biological, physical, chemical, and mineralogical proxy records that can be used to reconstruct past lacustrine environmental changes [1], including changes associated with storm events [2-4]. Major storms, especially hurricanes, and post-tropical storms can have a significant impact on sedimentation in lakes [5]. Past storm signals are often archived in lacustrine sediments as spikes of coarser-grained sedimentation

Supplementary Information The online version of this article (https://doi.org/10.1007/s42452-020-03908-3) contains supplementary material, which is available to authorized users.

R. Timothy Patterson, tim.patterson@carleton.ca | ${ }^{1}$ Department of Earth Sciences, Ottawa-Carleton Geoscience Centre, Carleton University, 1125 Colonel By Drive, Ottawa, ON K1S5B6, Canada. ${ }^{2}$ Department of Geography and Environmental Studies, Carleton University, 1125 Colonel By Drive, Ottawa, ON K1S5B6, Canada. ${ }^{3}$ School of Natural and Built Environment, Queen's University Belfast, Belfast BT71NN, UK. ${ }^{4}$ Geological Survey of Canada (GSC)/Commission géologique du Canada, Natural Resources Canada (NRCan)/Ressources naturelles Canada (RNCan), 3303 - 33 Street N.W., Calgary, AB T2L 2A7, Canada. ${ }^{5}$ School of Geography and Earth Sciences, McMaster University, 1280 Main St. W, Hamilton, ON K1S 5B6, Canada. 
within finer sedimentary deposits. The considerable precipitation that accompanies storms often intensifies sediment erosion of the surrounding catchment and runoff delivery of coarser sediments to lakes [1, 6], while strong storm winds are responsible for resuspending finer deep lake sediments through deepening the wave base [7-9]. Locating sediment archives that preserve such paleostorm signals in lakes systems can help with: (1) estimating the intensity and frequency of paleo-storms that occurred prior to human monitoring [10]; (2) placing current storm trends into a historical context; (3) modelling how known climate phenomena [e.g., Atlantic Multidecadal Oscillation (AMO), El Niño Southern Oscillation (ENSO)] modulate storminess; and, (4) anticipating future patterns [10, 11].

Lake sedimentary archive records are typically interpreted through analysis of core(s) collected from the deepest area (z-max) in a lake. This is because the z-max is better sheltered from the influences of wind driven wave base reworking $[11,12]$ and is likely to preserve thick, continuous, and undisturbed sedimentary archives of overall lake changes as a result of sediment focusing [13]. In the context of reconstructing paleo-storm activity, however, one drawback of coring the $z$-max is that this area of a lake is often distal from catchment derived sediment sources. As flowing water erodes the catchment and enters a lake, the velocity of flow decreases with distance from the source, progressively reducing the water's ability to move coarser sediment [14]. Therefore, it is difficult for storm eroded sediment to consistently make it to the z-max, resulting in dampened paleo-storm signals that are difficult to differentiate from background sedimentation [14]. In addition, for steep sided basins, turbidity currents or slope instabilities on the edges of deep basins sometimes results in sediment age reversals and other disturbances that negatively impact the archived paleoenvironmental record $[1,15]$. Thus, the identification of additional suitable coring sites that are removed from a lake z-max would be a useful addition for reconstructing paleo-storm events.

Locating sites of high paleo-storm signal preservation potential require coupling a multi-site characterization approach (i.e., intra-lake sampling) with assessment of lake proxies to define resuspension- and runoff-derived sedimentary deposits. Grain size analysis has been demonstrated to be a very useful indicator of lake depositional processes, which can be carried out quickly and is cost effective [16]. The development of end member mixing analysis (EMMA) techniques for the analysis of grain size distributions has been revolutionary, as it now permits researchers to more precisely model the depositional signature [i.e., end members(EM)] of specific catchment and lake hydrological processes [17-22]. The development of X-ray fluorescent (XRF) technology has revolutionized geological research as it can be used to analyze sediment geochemistry much faster and with lower cost than possible using traditional geochemical techniques [23-25]. Titanium (Ti) has been demonstrated to be a proxy of lake catchment runoff [26-30]. Mapping the distribution of this element in a lake basin using core scanning XRF techniques provides cost-effective data on sediment provenance, which permits researchers to identify areas of a lake receiving enhanced runoff, and therefore where paleo-Ti signals might be best preserved. Geomatics analysis of these proxies, combined with wind field data obtained from historical meteorological records, can be used to generate spatial models for the probability of wind waveinduced sediment mixing based on lake morphology (i.e., water column depth and lake fetch). Such spatial models can then be used to differentiate between resuspension and runoff derived deposition as well as the location of sites where robust paleo-storm signals may be preserved in lake sediments outside the $z$-max.

The purpose of this research was to test, using a novel geomatics protocol, the applicability of using multi-site intra-lake distributional data of two proxies: (1) EMMA of grain size data, in conjunction with calculated maximum storm associated wave base data, to identify the distribution of EM(s) associated with major storm derived sediment resuspension and allochthonous sedimentation; and (2) Ti data obtained using an Itrax XRF core scanner (CS) to determine areas of the lake where this proxy of runoff is most concentrated. The resultant probabilistic maps of the spatial variability of these proxies of catchment sedimentary dynamics were used to develop a foundation of understanding for the identification of optimal sediment coring sites for the preservation of paleo-storm records in Harvey Lake, in SW New Brunswick, Canada. Harvey Lake was chosen for the research due to the recent passage of Hurricane Arthur, which impacted the lake as a posttropical storm on July 5, 2014. This storm generated large wind waves in the lake that depressed the storm wave base and mobilized a considerable volume of lake bottom sediment into the water column, turning the entire water column brown for several days [personal communication, S. Bartlett, Chairperson New Brunswick Alliance of Lake Associations and former Chairperson Harvey Lake Association (HLA)]. There was also considerable runoff related to the storm as reported in a personal communication from HLA member Stephen Fox: "It (Arthur) took out our entire shoreline, primarily because the water rose so much and so rapidly. I remember that they had forecast the wind, but what no-one expected was the amount of rainfall". These anecdotal reports provide rationale as to why an inland lake, $\sim 80 \mathrm{~km}$ from the Bay of Fundy, is suitable for evaluating the impact of a recent major storm on lake wind field and the distribution of lake bottom sediments. 


\section{Harvey Lake physiography}

Harvey Lake $\left(45^{\circ} 43^{\prime} 45^{\prime \prime} \mathrm{N},-67^{\circ} 00^{\prime} 25^{\prime \prime} \mathrm{W}\right)$ is located adjacent to the village of Harvey, York County, New Brunswick, Canada (Fig. 1). The lake has a surface area of $7.2 \mathrm{~km}^{2}$ and a maximum depth of $11.8 \mathrm{~m}$. The inlet streams are relatively small, with Sucker Brook entering the lake at the head of Herbert's Cove, at the southwest corner of the lake, with Little Sucker Brook flowing into the lake midway along the eastern margin of the lake (Fig. 1). There is a small outlet stream, "The Harvey Lake Thoroughfare", midway along the western shore of the lake, which flows to Second Harvey Lake (also locally known as Mud Lake). Highway 636 runs north-south along the eastern margin of the lake with many homes and cottages positioned directly on the shore, with agricultural land behind them. There are also extensive wetlands along the northeastern and north shore, and in the area between Harvey and Second Harvey lakes. Cherry Mountain (160 m elevation) at the south end of the lake $\left(45^{\circ} 43^{\prime} 38^{\prime \prime} \mathrm{N} 67^{\circ} 00^{\prime} 59^{\prime \prime} \mathrm{W} ; 240 \mathrm{~m}\right.$ elevation) is comprised of Late Devonian-Early Carboniferous Harvey Group rocks, comprised here of the Cherry Hill and Harvey Mountain formations [31]. The $\sim 100 \mathrm{~m}$ thick exposure of the Cherry Hill Formation is comprised of quartz-feldspar-phyric densely welded ash-flow tuff ("quartz-feldspar porphyry"), with poorly welded ashflow sheets at the base, as well as other ignimbrites and volcaniclastic sedimentary rocks. The 75-100 m thick sequence comprising the Harvey Mountain Formation is characterized by pyroclastic breccia, laminated rhyolite lava flows and ignimbrites intercalated with ash-fall tuffs [32]. Sucker Brook flows through forest over outcrops of both the Harvey Mountain and Cherry Hill formations, while Little Sucker Brook passes through agricultural land over Silurian metasedimentary basement rocks [33].

\section{Methods}

\subsection{Field work}

One-hundred sediment-water interface samples were collected over two days in September 2015 from Harvey Lake using an Ekman grab sampler (Supplementary Table 1). Research material was obtained from the top $0.5 \mathrm{~cm}$ of sediments from each grab, which represents a potential average of $\sim 5$ years of sedimentation. The location for each sample station was determined using a Garmin GPSmap 76CSx GPS unit (Supplementary Table 1).
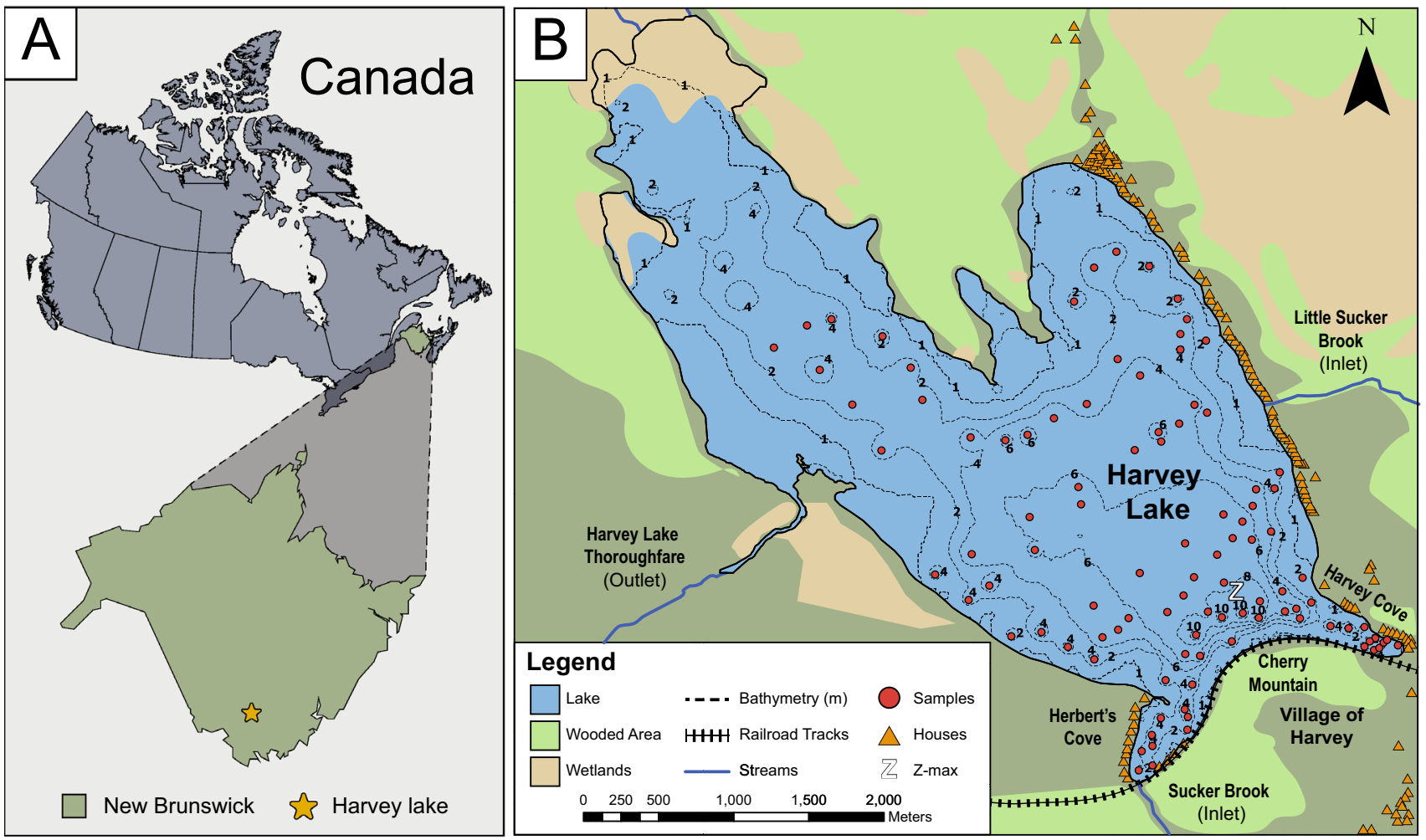

Fig. 1 a Location of Harvey Lake within Canada and province of New Brunswick. b An ArcGIS generated map of Harvey Lake showing area physiography, sample locations used in this research, and lake bathymetry 
The sediments were kept cool and transferred to Carleton University for subsequent analysis.

\subsection{Laboratory analysis}

\subsubsection{Grain-size analysis}

Prior to grain-size analysis, the 100 sediment subsamples were processed using a protocol modified from Murray [34] and van Hengstum et al. [35] where $30 \% \mathrm{H}_{2} \mathrm{O}_{2}$ was added to subsamples in an $80^{\circ} \mathrm{C}$ water bath to oxidize organic matter. Standard $\mathrm{HCl}$ pretreatment was deemed unnecessary as tests using $10 \% \mathrm{HCl}$ indicated that sediment carbonate content was insignificant. Treated subsamples were analyzed using a Beckman Coulter LS 13 320 laser diffraction grain size analyzer equipped with a universal liquid module. Suspended subsamples were pipetted into the analyzer until an obscuration of $10 \pm 3 \%$ was achieved. This slurry was circulated within the module for sixty seconds prior to the first of three replicate runs. Each sample was analyzed in triplicate producing grain size distributions ranging from $0.4-1500 \mu \mathrm{m}$ for each sample. The sample average was calculated from the analytical triplicates and Gradistat v8 was then used to generate summary statistics for the grain-size distribution data [36]. This distributional data was used as inputs for subsequent EMMA, as described in Sect. 3.3.3 below.

\subsubsection{Geochemistry (Itrax XRF-CS)}

All 100 sediment samples were analyzed using an Itrax high-resolution XRF-CS to provide a spatially comprehensive geochemical dataset. Although Itrax-XRF-CS is designed for analysis of sediment cores, a recently developed sequential sample reservoir vessel (SSRV) has now enabled analysis of discrete sediment samples [23]. Fifteen-cc aliquots were subsampled, and following the preparation protocol proposed by Gregory et al. [23], were analyzed using the Itrax XRF-CS instrument at the McMaster University Core Scanning Centre using a Mo-anode $\mathrm{X}$-ray tube, at $0.2 \mathrm{~mm}$ resolution, $15 \mathrm{~s}$ exposure time, $19 \mathrm{~mA}$ current and $30 \mathrm{kV}$ voltage. The results of Itrax XRF$\mathrm{CS}$ analysis for each sample were evaluated using the Cox Analytics RediCore software to refine the fit of predicted and observed elemental concentrations as determined by the Itrax software [24,37].

\subsection{Data analysis}

\subsubsection{Frequency of wind-induced resuspension}

A wind speed capable of generating a wave base equal to the water column depth in a lake will disturb the bottom substrate, resulting in sediment resuspension into the water column. Such a wind speed is termed the mixing speed for a specific depth, or sample station. The related wave base (WB), the maximum depth at which waveinduced resuspension of sediment occurs, is equal to:

$W B=0.25 \times L$

where $L$ is the wavelength of a deep-water wave $[7,38$, 39]. The deep-water wavelength is calculated based on the period, $T$, of a wave using the formula:

$L=1.56 \times T^{2}$

Equations (1) and (2) are then combined [Eq. (3)] to calculate the WB using the wave period:

$W B=0.39 \times T^{2}$

The period of a wave is determined using wind speed and fetch distance within the equation derived by $[40,41]$ :

$\frac{g T}{w}=0.46\left(\frac{g F}{w^{2}}\right)^{0.28}$

where $g$ is the acceleration due to gravity $(\mathrm{m} / \mathrm{s}), w$ is the wind speed $(\mathrm{m} / \mathrm{s})$ and $F$ is the fetch $(\mathrm{m})$. The maximum fetch, and largest potential waves for Harvey Lake, are derived from NNE tracking storms, where a maximum $5100 \mathrm{~m}$ length of open water is found. To estimate the mixing speed, depth and fetch were substituted into the equation. The results were subsequently translated into the Beaufort Wind Scale (BWS), a standardized ordinal scale ranging from $0-13$ for categorizing wind speeds (Table 1). It should be noted that the maximum fetch of $5100 \mathrm{~m}$ cannot be realized on Harvey Lake for many of the sample stations; for example, in the middle of the lake or in sheltered areas like Herbert's Cove. A more rigorous analysis, which is beyond the scope of this research, would base calculations on the longest uninterrupted distance to the shore in a straight line from any given point on the lake. The methodology used here provides a reasonable estimate of WB based on maximum values.

The historical probability of winds strong enough to induce lake bottom sediment resuspension is termed the mixing probability and is determined individually for each sample site. To calculate the mixing probability, hourly wind speed data covering the interval from 1953-2015 was obtained from the Fredericton INTL A climatological station (FIACS; $45^{\circ} 52^{\prime} 08.000^{\prime \prime} \mathrm{N}, 66^{\circ} 32^{\prime} 14.000^{\prime \prime}$ ), located $40 \mathrm{~km}$ to the ENE (68 ${ }^{\circ}$ bearing; [42]). Data from December to April, when ice typically covers Harvey Lake, were excluded as ice cover precludes winds from influencing the lake water column [42]. Individual CSV files, each representing a month of hourly logged meteorological 
Table 1 Hourly wind speed (km/h) data for the 1953-2015 interval from Fredericton INTL A climatological station (FIACS), located at the Fredericton International Airport, excluding winter months (December-March; [42]). The "Beaufort Wind Scale", "Description", Minimum "(Min.)" and Maximum "(Max.)" Speed columns represent end members within each Beaufort Wind Scale (BWS) category

\begin{tabular}{|c|c|c|c|c|c|}
\hline Beaufort wind scale & Description & Min. speed (km/h) & Max. speed (km/h) & Frequency (hours) & $\begin{array}{l}\text { Percent- } \\
\text { age } \\
\text { frequency }\end{array}$ \\
\hline 0 & Calm & 0 & 1 & 134,905 & 36.6 \\
\hline 1 & Light Air & 1 & 5 & 95,567 & 25.9 \\
\hline 2 & Light Breeze & 6 & 11 & 53,022 & 14.4 \\
\hline 3 & Gentle Breeze & 12 & 19 & 40,197 & 10.9 \\
\hline 4 & Moderate Breeze & 20 & 28 & 32,630 & 8.9 \\
\hline 5 & Fresh Breeze & 29 & 38 & 10,115 & 2.7 \\
\hline 6 & Strong Breeze & 39 & 49 & 2159 & 0.6 \\
\hline 7 & Near Gale & 50 & 61 & 120 & 0.03 \\
\hline 8 & Fresh Gale & 62 & 74 & 13 & 0.004 \\
\hline 9 & Strong Gale & 75 & 88 & 0 & 0 \\
\hline 10 & Whole Gale & 89 & 102 & 0 & 0 \\
\hline 11 & Violent Storm & 103 & 117 & 0 & 0 \\
\hline 12 & Hurricane & 118 & $>252$ & 0 & 0 \\
\hline
\end{tabular}

[43]. The "Frequency (hours)" header listed is the number of hours from 1953-2015 when wind speeds recorded at FIACS correlated with the various BWS categories. The related "Percent Frequency" indicates the relative amount of time that particular wind speeds within the BWS prevailed data, were merged into a single dataset using the Pandas, Glob and Os modules of the Python computer programming language (version 3.7.4). Python and the Pandas and Numpy modules were used to bin the hourly data by wind speed $(\mathrm{km} / \mathrm{h})$ according to the BWS to generate the frequency, cumulative sum and percentage of occurrence.

\subsubsection{Itrax XRF-CS}

Itrax XRF-CS results are considered semi-quantitative as variations in sediment bulk density, sediment surface roughness, and proportion of organic and water content can interfere with XRF-CS signal in a non-linear fashion [44]. Comparison of Itrax-XRF-CS results to select subsamples analyzed using traditional methods of near-total sediment geochemistry can be used to ensure relative variations accurately approximate trends in sediment geochemistry. Previous comparisons of XRF-CS and traditional methods of whole-rock geochemical analysis have shown that correction for variations in water content improve correlations $[24,45,46]$. The Itrax-XRF results were here adjusted to account for variations in water content in sediment following Boyle et al. [45]. Following the Itrax-XRF-CS analysis sediments where removed from the SSRV, placed into clean, dried crucibles, weighed, then and dried in an oven at $100{ }^{\circ} \mathrm{C}$ for $24 \mathrm{~h}$. The difference in weight before and after drying was used to estimate water content in samples. The percent dry mass of samples was compared to a ratio of coherent to incoherent X-ray scatter (CIR) using linear regression. There was a strong, statistically significant correlation between water content and CIR (Spearman's $\rho=0.94, p$ value $<0.001, n=61$ ). The equation of linear regression was thus used to correct Itrax-XRF elements to "dry weight" based on the formula provided by Boyle et al. [45]:

$D_{j i}=l_{j i}\left(\frac{100}{\omega_{i}}\right)$

where $D_{j i}$ represents the dry mass concentration of an element $j$ at interval $i$ as measured by XRF-CS, $l_{j i}$ represents the XRF intensity of element $j$ measured at interval $i$, and $\omega_{i}$ represents the percent dry mass at interval $i$.

To estimate the reliability of the Itrax-XRF-CS analysis, these results were compared to ICP-MS analysis results of select aliquots from the same set of samples. The ICP-MS analysis was conducted on 28 Harvey Lake samples with 10 triplicates (48 samples total) at the Bureau Veritas Mineral Laboratories, Vancouver, British Columbia following a four-acid digestion technique (DYAIR, PULCB and MA250 packages). Comparison of wet-corrected XRF-CS data to ICP-MS results showed a moderate-strength correlation for Titanium (Spearman's $\rho=0.47 ; p$ value $<0.001 ; n=48$ ). Wet-corrected Ti results were therefore used as a proxy for Ti variations in the Harvey Lake sediment-water interface samples. 


\subsubsection{End member mixing analysis (EMMA)}

EMMA is a methodology used to provide a genetic interpretation of multi-modal grain size distributions with minimal assumptions [18, 20, 21]. EMs are modeled by un-mixing multi-modal distributions that are comprised of the sum of many depositional processes, and the resultant EMs can then be associated with specific depositional processes [19]. EMMA was carried out using the grain-size analysis results from the 100 analyzed Harvey Lake stations to characterize depositional processes influencing sedimentation in the lake. The EMMA analysis protocol following that of [18] using extensions implemented in the R-Studio package EMMAgeo v. 0.9.7 [17]. Only robust EMs were included, defined as those with non-overlapping, interpretable EM loadings, with the addition of those in which similar EM loadings occurred in most of the model runs [18].

\subsubsection{Geospatial data handling}

Kriging was used to visualize the geospatial distribution of measured analytical results for Harvey Lake. Kriging is a spatial interpolation method that predicts probable values for an unsampled target location using a linear combination of observed values at nearby sample locations, the distance between the observed values and the prediction location, and the overall spatial arrangement of the measured points as quantified by a semivariogram [47]. Semivariograms are graphs that show how semivariance changes as the distance between observations changes. Semivariograms are thus useful for measuring the degree of dissimilarity between observations as a function of distance [48]. With the interpolation approach used with kriging, a value is ascribed to a grid cell based upon the values from known points. Interpolation weights are based not only on the distance between the measured points and the prediction location, but also on the overall spatial arrangement of the measured points. Spatial and nonspatial statistical methods, such as kriging, have played an important role in geochemical pattern recognition in lakes [49]. Results displayed in a spatial manner facilitate the identification of depositional areas and catchment influences, which is important for designing subsequent sampling plans for future field work (e.g., [50]).

Ordinary kriging, which is the most widely used form of spatial interpolation among the various kriging methodologies [51], was used to generate continuous maps of the results throughout the entirety of the Harvey Lake basin. The default ordinary kriging setting of 12 nearby data points was used to interpolate the value of each given cell for the analysis. Shapefiles for Harvey Lake, local water bodies and rivers, and natural and anthropogenic land use were retrieved from the GeoGratis Database [52].

\subsubsection{Spearman rank correlation}

A Spearman's rank correlation $(\rho)$ correlogram was used to explore the distribution of the measured variables and their relationships to one another. Although the Spearman correlation between two variables is equal to the Pearson correlation between the rank values of those two variables Spearman's is the appropriate analytical approach with the Harvey Lake data. This is because the Pearson's correlation is more appropriate for assessing linear relationships, while the nonparametric Spearman's correlation assesses monotonic relationships (whether linear or not), which best describes the Harvey Lake data sets. The "stats" package in $\mathrm{R}$ was used to generate Spearman correlation matrix and correlogram ([53]; Supplementary Table 1).

\section{Results}

\subsection{Lake bottom sediment mixing probability}

An estimate of the frequency of wind speeds $(\mathrm{km} / \mathrm{h})$ impacting Harvey Lake was derived from wind-speed data for the 1953-2015 interval, excluding the winter months (December-March), and was based on data obtained from the FIACS. This data was binned according to the 12 subdivision of the BWS according to frequency of events, cumulative sum of events and percentage of time when a particular wind speed category would have been present or exceeded (Table 1). There were no recorded events at the FIACS where wind velocities exceeded a fresh gale $(62-74 \mathrm{~km} / \mathrm{h})$, which is category 8 on the BWS. The frequency of wind category events was converted to the percent of time when particular wind conditions were present using a cumulative sum.

The spatial distribution of mixing speeds (i.e., the wind speed required to generate wave-induced resuspension at a given location and water depth; see Sect. 3.3.1) is shown in Fig. 2. For example, at the Harvey Lake z-max (depth $=11.8 \mathrm{~m}$; Fig. 1) in the south central part of the lake the required mixing speed to resuspend sediments at that depth is $>118 \mathrm{~km} / \mathrm{h}$ (i.e., BWS Category 12 - Hurricane), while the mixing speed required to resuspend sediments in the deepest part of Herbert's Cove (shallowest depth near head of cove $=2.9 \mathrm{~m}$ ) is $20-28 \mathrm{~km} / \mathrm{h}$ [i.e., BWS Category 4- Moderate Breeze (Fig. 1; Table 1)]. The shallow margins of Harvey Lake where the lake bottom is only a few $\mathrm{cm}$ deep requires only BWS Category $0-1$ (Calm to Light Air; $0-5 \mathrm{~km} / \mathrm{h}$ ) conditions to induce sediment resuspension [54]. 


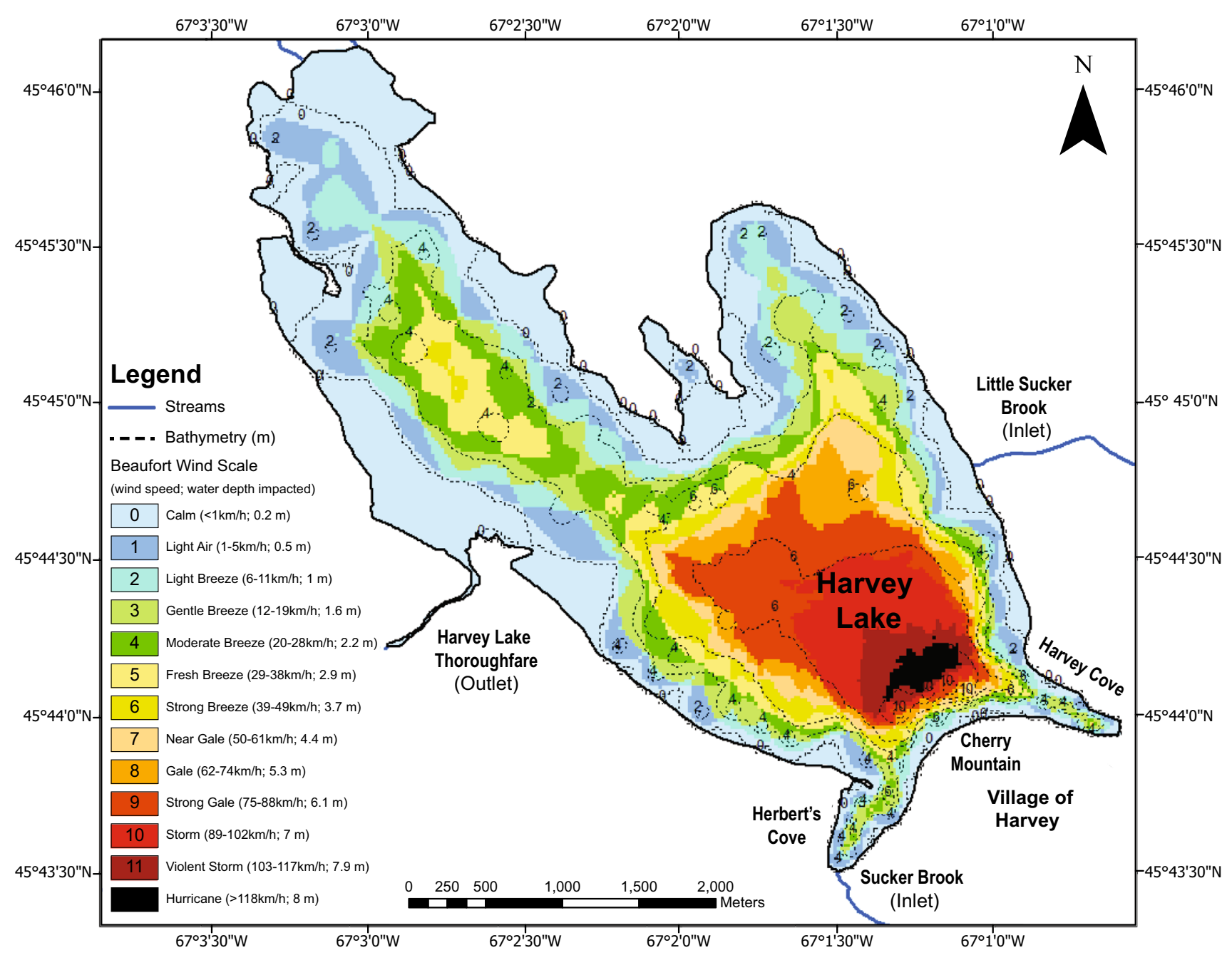

Fig. 2 Spatial bathymetric map of Harvey Lake displaying the wind speed required in terms of the 12 Beaufort Wind Scale categories to generate a wave base mixing speed capable of resuspending lake bed sediments at a given water depth and location. Wind speed

By combining the percent of time that certain wind speeds historically occurred (Table 1) with the spatial distribution of historical mixing speeds (Fig. 2) it is possible to model the spatial distribution of mixing probability (i.e., the frequency that the wind speed required to induce resuspension occurs [Fig. 3; see Sect. 3.3.1)]. The lake bottom sediment mixing probability and water depth are characterized by a negative relationship with deeper parts of Harvey Lake requiring significantly higher wind mixing speeds to cause substrate resuspension than in shallower water areas. On the margins of Harvey Lake, where BWS Category 0-1 (Calm conditions; $0-1 \mathrm{~km} / \mathrm{h}$ ) is always met or exceeded in the few $\mathrm{cm}$ water depth present, sediments are perpetually being resuspended. The wind conditions required to resuspend sediment deposited below $>4.4 \mathrm{~m}$ in the lake have not been observed at the Fredericton International A Climatological Station during the calculations were based on the 1953-2015 May-November (open water season) Fredericton International A Climatological Station wind speed dataset, located $40 \mathrm{~km}$ to the NE

1953-2015 interval and resuspension of sediments in the deepest part of the lake at $\sim 11 \mathrm{~m}$ would require hurricane strength winds ( $>118 \mathrm{~km}$ per hour; Table 1 ). These observations of course do not preclude deposition of sediment in deeper water that has been resuspended into the water column at shallower water depths and then transported laterally before being redeposited in water depths $>4.4 \mathrm{~m}$ [54].

\subsection{Titanium}

The z-max region of Harvey Lake was characterized by the highest concentrations of the catchment runoff proxy $\mathrm{Ti}$ in the lake $\left[\sim 8100\right.$ adjusted counts per second (cps ${ }_{\text {adj; }}$; range $=6771$ to $9794 \mathrm{cps}_{\mathrm{adj}}, n=9$ ); Fig. 4, Supplementary Table 1]. Elevated Ti concentrations were also observed in Herbert's Cove near the inflow of Sucker Brook to the 


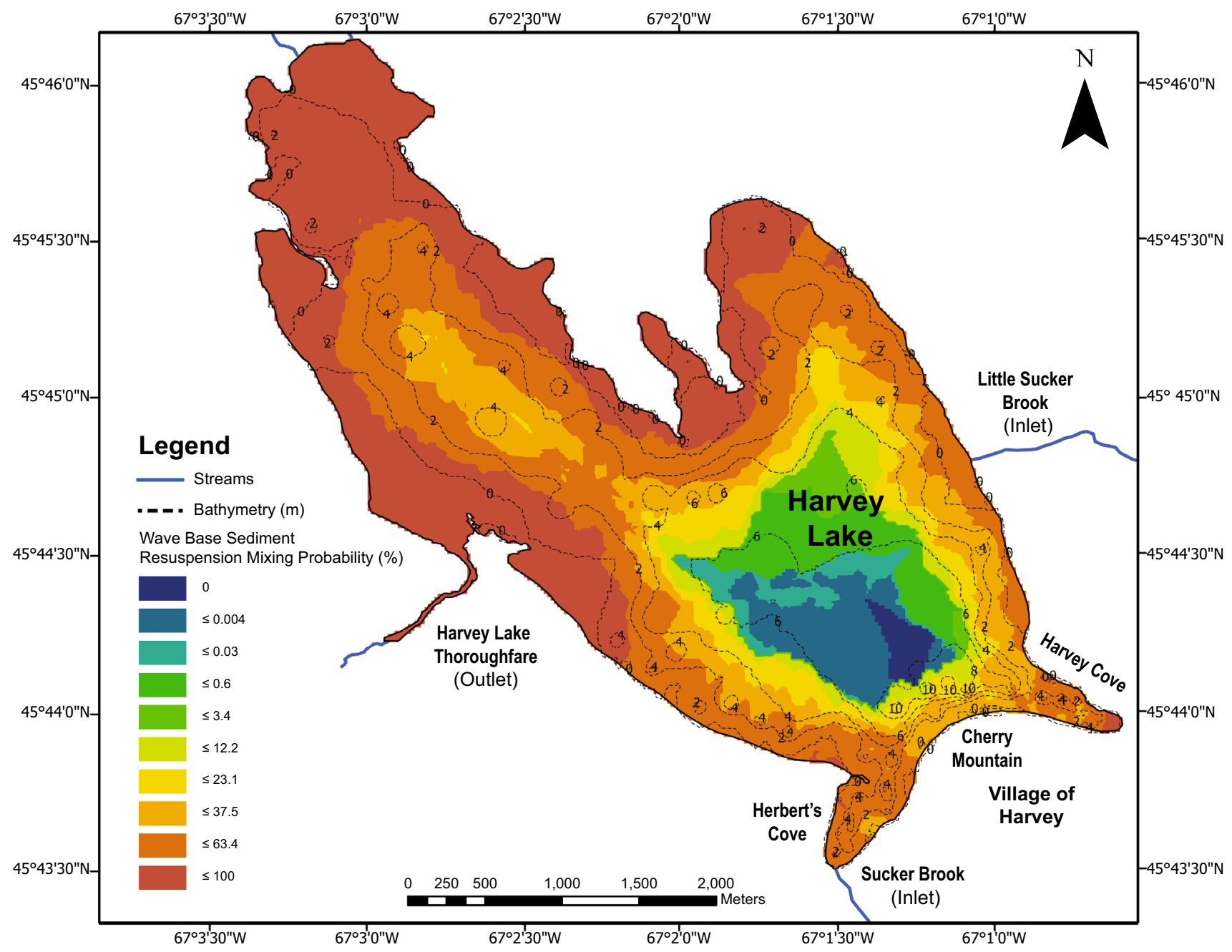

Fig. 3 Map of Harvey Lake displaying the spatial distribution of the theoretical wave base mixing probability (\%) for sediment resuspension to occur. For example, the very shallow margins of the lake are characterized by a $100 \%$ percent probability substrate sediments being resuspended

value that measures the variability in modeling the EM's grain size distribution; the greater the variability the less robust the EM. Of the robust EMs, the very coarse silt EM02 (mode $=40 \mu \mathrm{m})$ explained the most particle size bin-wise variation in the Harvey Lake grain size dataset (42\%; Fig. 5). This EM, the only EM to be characterized by a unimodal grain size distribution, was abundant in the southwest region of Harvey Lake (73.5-93.6\%), particularly in an area in the central part of the lake. It is also abundant at the z-max and the outer area of Herbert's Cove (Fig. 6a). The fine silt EM01 (6 $\mu \mathrm{m})$ and fine sand EM03 $(177 \mu \mathrm{m})$ also explained significant proportions of the bin-wise variance in the grain size dataset (24\% and $22 \%$, respectively) and exhibited secondary modes (Fig. 5). Both EM01 and EM03 are most abundant in the northern part of the lake (Fig. 6b). While robust, the medium sand EM04;
The selected EMMA model explained $79.7 \% \pm 13.0 \%$ of the variance in the Harvey Lake surface sediment grain size dataset and consisted of four robust EMs (EMs 01-04). In the context of EMMA the term 'robust' is a quantifiable

\section{SN Applied Sciences}




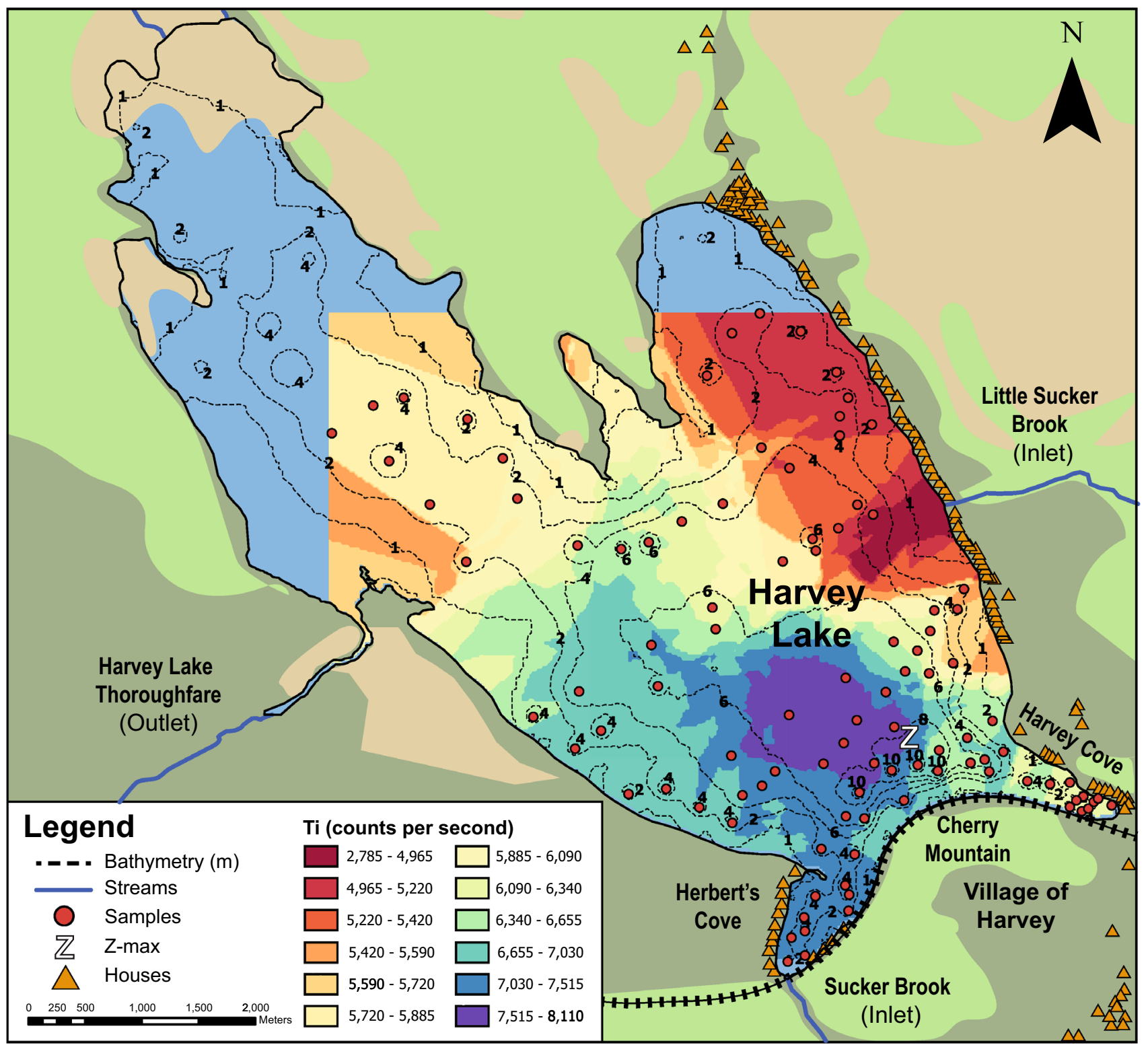

Fig. 4 Spatial distribution of Ti concentrations in counts per second (CPS) as calibrated from Itrax XRF CS analysis results from from the analyzed sample stations (Supplementary Table 1)

mode $=450 \mu \mathrm{m}$ ) only explained $\sim 9 \%$ of the bin-wise variation in the dataset, and displayed no recognizable distribution pattern (Figs. 5, 6b).

\subsection{Spearman rank correlation coefficients}

The Spearman's correlation results indicated that there was a high-strength, statistically significant correlation between EM 02 and Beaufort Wind Mixing Speed (0.69, $\rho=<0.001$; Fig. 7). The EM 02 is the only robust EM to have a positive correlation with this storm related measure. It is also notable that there is a similar and expected statistically significant correlation between runoff derived $\mathrm{Ti}$ and wind mixing speed $(0.55, \rho=<0.001)$. There is also a very strong correlation between $\mathrm{Ti}$ and EM 02 ( 0.59 , $\rho=<0.001$; Fig. 7). This is because major storms are generally not only characterized by high winds that depress WB, but by heavy rains that result in higher levels of runoff from the catchment. 

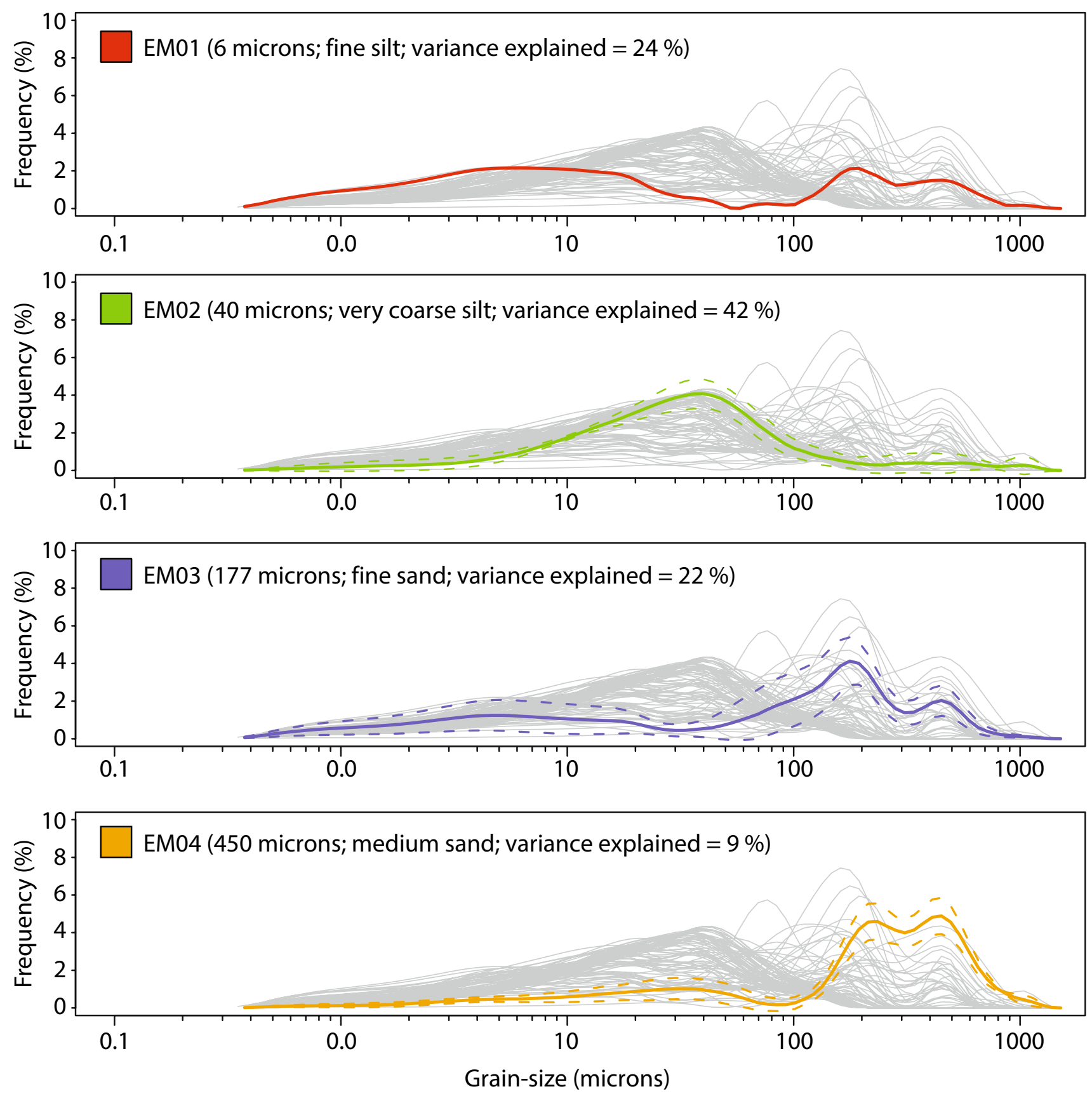

Fig. 5 Grain size frequency distributions for all 100 analyzed samples (grey), as well as the distribution of the four derived robust end members derived from the selected EMMA model that best explained the sediment grain distribution in the analyzed samples

\section{Discussion}

\subsection{Sediment resuspension}

Sediment undergoes resuspension when orbital movements within the water column derived from wind action at the surface exceeds a critical shear stress at the lake bottom [55]. This results in lake bottom sediments being suspended into the water column and displaced, negatively impacting the preservation of complete environmental archives $[55,56]$. Thus, areas of lake bottoms with minimal wind-induced sediment mixing should be targeted 

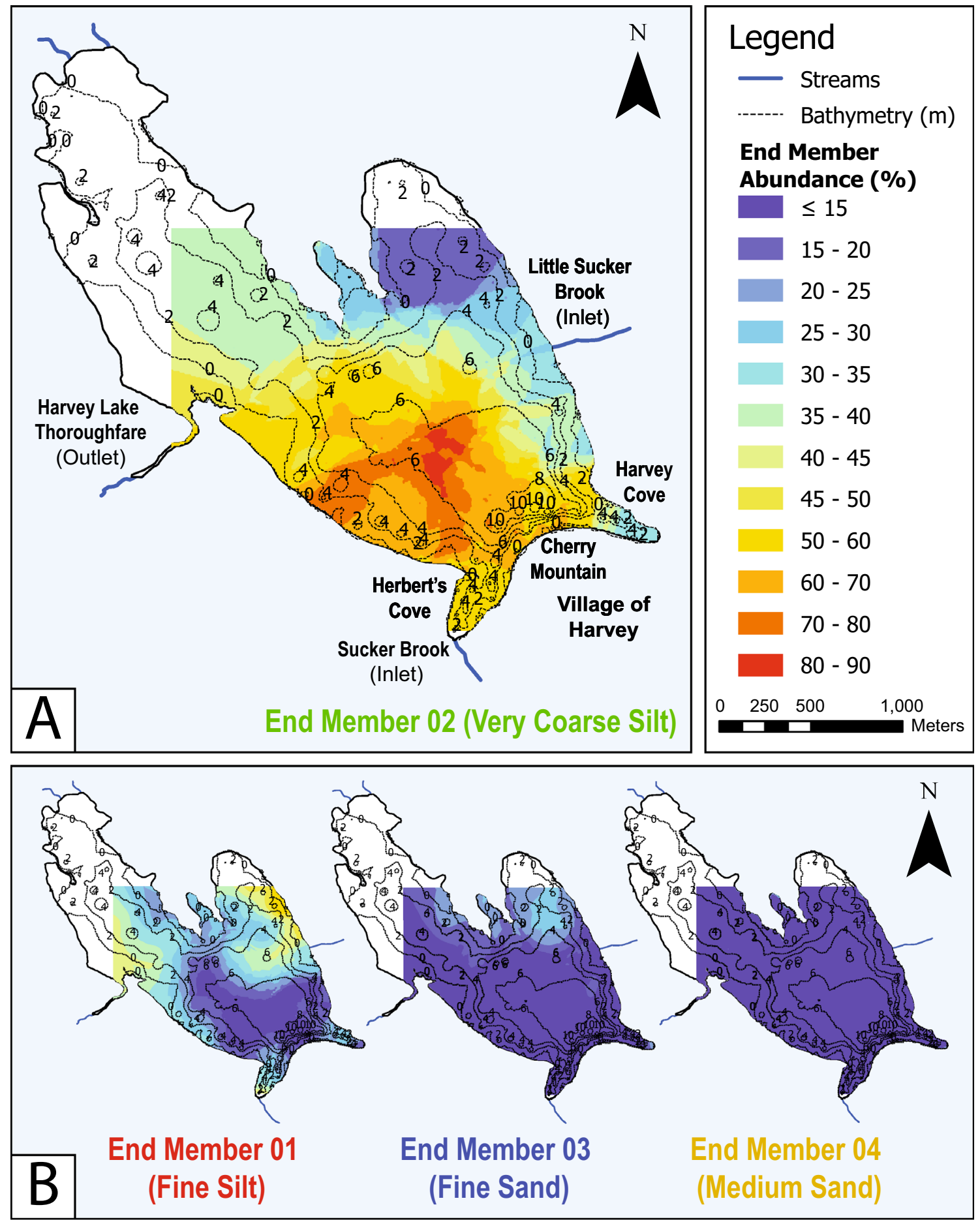

Fig. 6 a Spatial map of Harvey Lake displaying the concentration of the very coarse silt end member (EM02; mode $=40 \mu \mathrm{m})$, interpreted to represent storm driven sediment resuspension and subsequent redeposition. b Concentration of EMs 01, 03, 04 in Harvey Lake

to recover the most undisturbed paleoenvironmental archives.

In Harvey Lake, depositional lake bottom areas potentially harboring undisturbed sedimentary archives are most likely to occur in areas characterized by a mixing probability of $<5 \%$. The most promising areas meeting these criteria are restricted to the southwest part of the lake including the $z$-max, which has a mixing probability of $0 \%$, and the sheltered outer margin of Herbert's Cove, which is also characterized by a very low mixing 


\section{Spearman Rank Correlation}

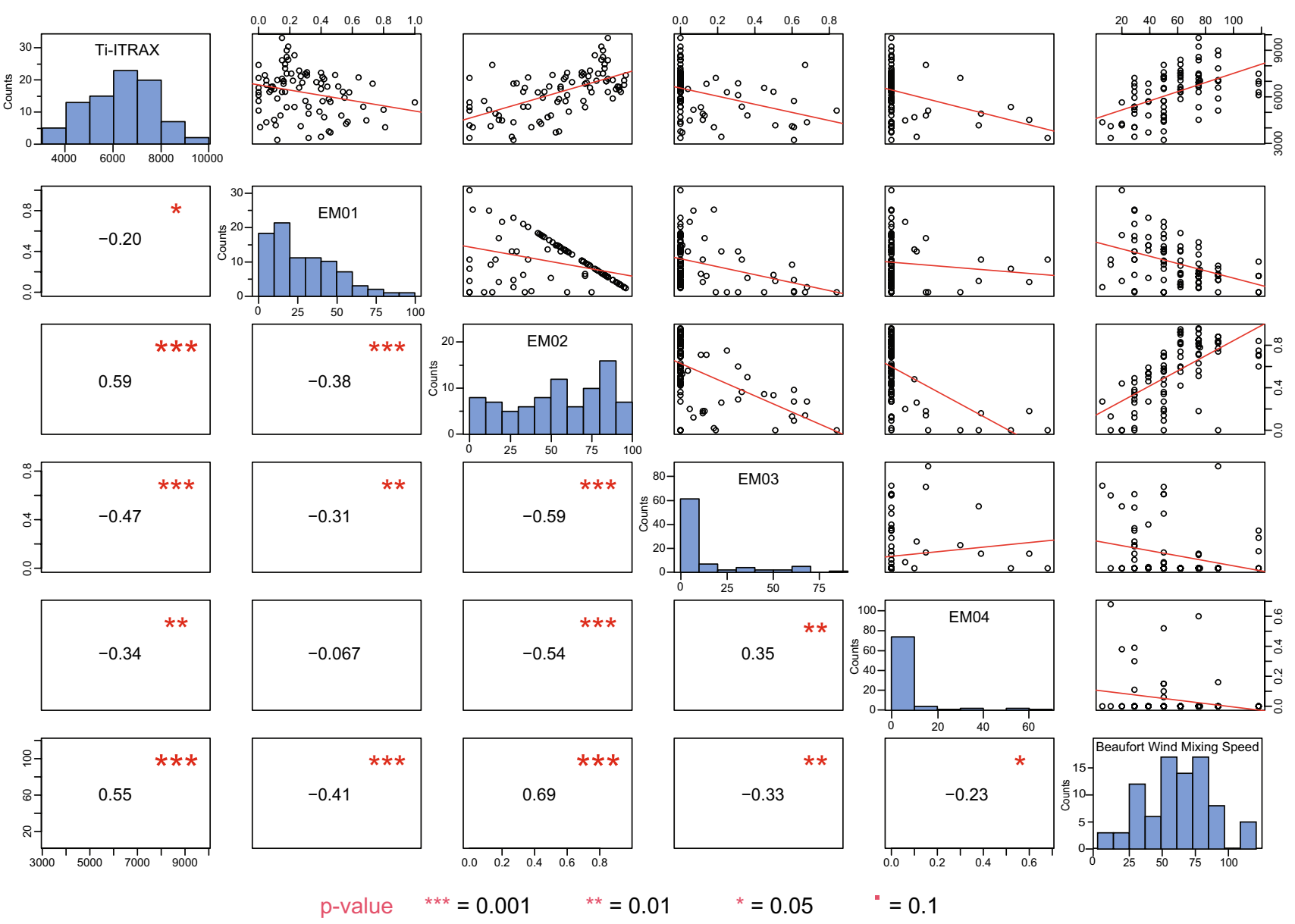

Fig. 7 Spearman's correlation matrix of select Harvey Lake variables [Itrax-XRF derived Titanium CPS, EM 01, EM 02, EM 03, EM 04, and Beaufort Wind Mixing Speed (BWMS)]. The strongest correlation is

probability of $3.4 \%$ (Fig. 3). Harvey Cove, adjacent to the Village of Harvey, has similar characteristics to Herbert's Cove, but has unfortunately been negatively impacted by the deposition of wood chips and other debris derived from decades of runoff from the now closed lumber mill operations. There is so much wood debris on the bottom of Harvey Cove that it was very difficult to collect Eckman grab samples from this location.

The EMMA model analysis resulted in recognition of a robust, very coarse silt EM 02 (mode $=40 \mu \mathrm{m}$ ) robust EM that had a strong positive correlation with wind mixing speed $(0.69, \rho=<0.001$; Fig. 7). This end-member is found draping deeper water areas of Harvey Lake with low likelihood of being impacted by a wind induced deepening of WB, including the z-max, as well as Herbert's and Harvey coves (Figs. 5, 6, 7). Areas of Harvey Lake protected from local sediment resuspension are not immune however to fallout from sediments that are resuspended in the water between EM 02 and BWMS (0.69) with similarly strong correlations between Ti-ITRAX and BWMS (0.55) and Ti-ITRAX and EM02 (0.59)

column elsewhere in the lake, carried by wind generated waves throughout the entire lake body, and which sink to the substrate again once turbulence in the water column is reduced (Figs. 5, 6). EM 02 is thus interpreted to be most likely the product of sediment resuspension during storm events, which is then subsequently redeposited in quieter deeper water areas of Harvey Lake. EMMA has similarly been used to identify the sedimentary record of a particularly strong 1953 North Sea storm surge in a UK salt marsh on the UK Norfolk Coast [57]. The identification of the highest proportions of EM 02 in the central part of the lake, as well as significant concentrations at both the z-max and at the outer margins of Herbert's Cove suggests that EMMA analysis of core records from these areas of the lake might result in detection of paleo-storm signals archived in the sedimentary record (Fig. 6). 


\subsection{Catchment sediment runoff}

Allochthonous sediments are an important catchment runoff proxy that are often directly related to storm precipitation events, given that variation in grain size distributions reflects different transportation and depositional processes [58-60]. The high precipitation rate associated with major storm events increases soil erosion within the catchment, enhances sediment transport capacity of streams, and delivers coarser material into a lake $[8,9]$. These processes may in turn be modulated over time due to regional climate variability [8].

The primary potential sources of allochthonous sediment runoff into Harvey Lake include the steep slopes of Cherry Mountain on the south shore of the lake, Little Sucker Brook that drains through cleared agricultural land, and Sucker Brook, which flows through forest into Herbert's Cove (Fig. 1). A primary destination for sediment runoff in Harvey Lake is the z-max, as it is relatively close to a potential primary source of allochthonous sediment source, Cherry Mountain. The z-max of any lake is generally considered the ideal target for coring studies since sediment derived from throughout an entire lake may end up focusing there (Fig. 1; $[8,15])$. However, after 1869 when a rail line was constructed along the base of Cherry Mountain on the Harvey Lake shoreline [61], the dam formed by the elevated track bed has made it much more difficult for sediment from this source to reach the lake. In addition, there is little to erode from the rail bed itself as it is primarily constructed of quarried granitic blocks.

As has been demonstrated elsewhere the distribution of elemental Ti throughout the Harvey Lake basin provides data on what areas of the lake are best suited to collect cores where this proxy of runoff might be preserved (e.g., [26-30]). For example, the area of the lake at the mouth of Little Sucker Brook, has the lowest levels of Ti measured in the lake, suggesting that the agricultural lands drained are not a significant source of this runoff proxy (Fig. 5). This part of the eastern shore of Harvey Lake also has a high mixing probability that results in frequent resuspension events, which preferentially winnow away fine grains leaving the observed coarser sediments behind $[1,62,63]$. As this part of the lake is subject to considerable reworking cores collected here would primarily archive a highly reworked sedimentary record preserving little evidence of paleo-storm and related catchment runoff activity.

In contrast the SW part of Harvey Lake, including the z-max and Herbert's Cove are characterized by the highest levels of Ti recorded in the lake (7515-8105 cps; Fig. 4). The distribution of Ti indicates that Sucker Brook is the main source of Ti into the lake, where it flows through Herbert's Cove and out into the main lake basin, with focusing occurring in the z-max. The elevated Ti levels in Herbert's
Cove and the z-max are mostly likely originating from the breakdown of $\mathrm{TiO}_{2}$ in Ilmenite, which is a mineral common in the volcanic deposits comprising the Harvey Group rocks over which Sucker Brook flows [32].

The distribution of $\mathrm{Ti}$ is lower along the shoreline adjacent to Cherry Mountain, indicating that this topographic high, although comprised of Harvey Group volcanic rocks is presently not a direct major contributor of Ti into the lake basin. The New Brunswick Southern Railway operates a rail line, constructed in 1869, that runs along the southwestern shore of Harvey Lake between the foot of Cherry Mountain and the lake shore [61]. The constructed raised berm upon which the tracks were built to keep a constant elevation forms an effective barrier to runoff from Cherry Mountain into the lake, thus explaining the lower Ti levels found along the shoreline there.

\section{Summary and conclusions}

Lake depositional systems are comprised of sedimentary archives that potentially preserve signals of past storms as spikes of coarser-grained sedimentation within an otherwise finer grained sedimentary record. These particles are derived from: (1) the greater precipitation generally associated with storm events, which increases runoff from the catchment into inlet streams, resulting in coarser grains being carried into a lake [1, 6]; and (2) sediments resuspended from the substrate by wind associated with storm events, which eventually resettle to the lake bottom even in areas below the storm WB ( $>4.4 \mathrm{~m}$ maximum in Harvey Lake) once the storm abates, in a fining up sequence ([64]; Fig. 2). Locating sedimentary lake archives that record sedimentation events but are not subject to WB reworking are valuable as they could potentially enable researchers to observe past trends in storm intensity and frequency, and place present-day storm events into an historical context $[65,66]$. The capacity to identify storm events predating instrumental records is particularly valuable as this information can be used to better understand the past trends and cycles of climate drivers known to influence major storm intensity and frequency in the North Atlantic region (e.g. AMO, ENSO; $[67,68])$; important data for researchers modeling future storm patterns.

Our analysis of wind mixing probability, the distribution of the storm associated very coarse silt EM (mode $=40 \mu \mathrm{m}$ ) and Ti has identified an area just north of the Harvey Lake z-max as the best potential area to collect sediment cores for future paleo-storm assessment studies that preserves records of both proxies (Figs. 4, 6). The z-max and the deeper-water outer margin area of Herbert's Cove are also potentially good candidates for subsequent paleo-storm studies as well, although with caveats. In general, z-max 
sites tend to be preferred over shallower sites, particularly if they are characterized by a flat central basin [15]. The relatively small area and steep slopes associated with the $>11$ m deep z-max in Harvey Lake are potentially problematic as background level sediment runoff from the Cherry Mountain topographic high that occurred prior to the construction of the railway line in 1869 , may have resulted in slope instabilities and slumping into the z-max unrelated to storm activity. In contrast, sediments from the deeper water areas (up to $6 \mathrm{~m}$ ) of the sheltered Herbert's Cove are not only protected from WB sediment reworking, but contain a record of the resuspended very coarse silt EM02 sediments (Fig. 6). In addition, as indicated by the measured Ti levels, this area of the lake also receives high storm precipitation derived allochthonous sediment inputs (Fig. 4). Ideally cores collected to document the paleo-storm archive of Harvey Lake would be collected from both Herbert's Cove and the area north of the z-max, to provide intrabasinal corroboration of any recognized paleo-storm events.

This research has demonstrated that prior to collecting lake cores for the assessment of potential paleo-storm event intensity and frequency, that a careful geospatial analysis of a potential target lake be carried out. In the case of Harvey Lake, it was first assumed that the z-max would be the optimal coring target area, but based on the results of this research, the outer areas of Herbert's Cove and an area north of the z-max are most likely the best locations for the collection of cores that will potentially archive the best paleo-storm records.

Acknowledgements This work was supported by NSERC Discovery (\#RGPIN05329) and NRCan Clean Technology (\#CGP-17-0704) grants to RTP. We thank Jochen Schroer of NATECH Environmental Services for providing a shapefile for the baseline Bathymetry Map. We also acknowledge the contributions of Dr. Sheryl Bartlett, chairperson New Brunswick Alliance of Lake Associations and past chairperson of the HLA for facilitating the research on Harvey Lake. We thank Roy T. Patterson for contributing his time and a boat for sample collection and to Zacchaeus Compson, University of New Brunswick, for aiding in the field collection of samples. We acknowledge the very helpful comments and data checking provided by an anonymous reviewer that significantly improved the manuscript.

\section{Compliance with ethical standards}

Conflict of interest The authors declare that they have no conflict of interest.

\section{References}

1. Cohen AS (2003) Paleolimnology: the history and evolution of lake systems. Oxford University Press
2. Eden DN, Page MJ (1998) Palaeoclimatic implications of a storm erosion record from late Holocene lake sediments, North Island, New Zealand. Palaeogeogr Palaeoclimatol Palaeoecol 139:37-58

3. Hesser TJ, Cialone MA, Anderson ME (2013) Lake St. Clair: storm wave and water level modeling. Great Lakes Coastal Flood Study 2012. Federal Inter-Agency Initiative. Coastal and Hydraulics Laboratory. ERDC/CHL TR-12-26, p 312

4. Jensen RE, Cialone MA, Chapman RS, Ebersole BA, Anderson $M E$, Thomas $L$ (2012) Lake Michigan storm: wave and water level modeling. Great Lakes Coastal Flood Study 2012. Federal InterAgency Initiative. Coastal and Hydraulics Laboratory. ERDC/CHL TR-12-26, p 312

5. Oliva F, Viau AE, Person MC, Bouchard M (2018) Paleotempestology database for the western North Atlantic basin. Holocene 28(10):1664-1671. https://doi.org/10.1177/0959683618782598

6. Gallagher E, Wadman H, McNinch J, Reniers A, Koktas M (2016) A conceptual model for spatial grain size variability on the surface of and within beaches. J Mar Sci Eng 4:38

7. Dean RG, Dalrymple RA (1991) Water wave mechanics for engineers and scientists, Advanced Series on Ocean Engineering, vol 2. World Scientific, Singapore. ISBN: 978-981-02-0420-4

8. Hakanson L, Jansson M et al (1983) Principles of lake sedimentology. Spriinger, Berlin, p 316

9. Peng Y, Xiao J, Nakamura T, Liu B, Inouchi Y (2005) Holocene East Asian monsoonal precipitation pattern revealed by grain-size distribution of core sediments of Daihai Lake in Inner Mongolia of north-central China. Earth Planet Sci Lett 233:467-479. https ://doi.org/10.1016/j.epsl.2005.02.022

10. Oliva F, Peros M, Viau A (2017) A review of the spatial distribution of and analytical techniques used in paleotempestological studies in the western North Atlantic Basin. Prog Phys Geogr 41:171-190

11. Page MJ, Trustrum NA, DeRose RC (1994) A high resolution record of storm-induced erosion from lake sediments, New Zealand. J Paleolimnol 11:333-348. https://doi.org/10.1007/BF006 77993

12. Naya T, Amano K, Okada M, Nakazato R, Kumon F, Nirei H (2004) Characteristics of bottom surface sediments in relation to wind and wave action in Lake Kitaura, central Japan. J Geol Soc Jpn 110:1-10. https://doi.org/10.5575/geosoc.110.1

13. Flower RJ, Stickley C, Rose NL, Peglar S, Fathi AA, Appleby PG (2006) Environmental changes at the desert margin: an assessment of recent paleolimnological records in Lake Qarun, Middle Egypt. J Paleolimnol 35:1-24

14. Morales-Marin L, French J, Burningham H, Battarbee R (2018) Three-dimensional hydrodynamic and sediment transport modeling to test the sediment focusing hypothesis in upland lakes. Limnol Oceanogr 63:S156-S176

15. Last WM, Smol JP (2001) An introduction to Basin analysis, coring, and chronological techniques used in paleolimnology. In: Last WM, Smol JP (eds) Tracking environmental change using lake sediments: Basin analysis, coring, and chronological techniques. Springer Netherlands, Dordrecht, pp 1-5. https://doi. org/10.1007/0-306-47669-X_1

16. Gammon PR, Neville LA, Patterson RT, Savard MM, Swindles GT (2017) A log-normal spectral analysis of inorganic grain-size distributions from a Canadian boreal lake core: towards refining depositional process proxy data from high latitude lakes. Sedimentology 64:609-630. https://doi.org/10.1111/sed.12281

17. Dietze E, Dietze $M$ (2019) Grain-size distribution unmixing using the R package EMMAgeo. EGQSJ 68:29-46. https://doi. org/10.5194/egqsj-68-29-2019

18. Dietze E, Hartmann K, Diekmann B, IJmker J, Lehmkuhl F, Opitz S, Stauch G, Wünnemann B, Borchers A (2012) An end-member algorithm for deciphering modern detrital processes from lake 
sediments of Lake Donggi Cona, NE Tibetan Plateau, China. Sediment Geol 243:169-180

19. Macumber AL, Patterson RT, Galloway JM, Falck H, Swindles GT (2018) Reconstruction of Holocene hydroclimatic variability in subarctic treeline lakes using lake sediment grain-size endmembers. Holocene 28:845-857. https://doi.org/10.1177/09596 83617752836

20. Weltje GJ, Prins MA (2003) Muddled or mixed? Inferring palaeoclimate from size distributions of deep-sea clastics. Sediment Geol 162:39-62. https://doi.org/10.1016/S0037-0738(03)00235 $-5$

21. Weltje GJ, Prins MA (2007) Genetically meaningful decomposition of grain-size distributions. Sediment Geol 202:409-424. https://doi.org/10.1016/j.sedgeo.2007.03.007

22. Dalton AS, Patterson RT, Roe HM, Macumber AL, Swindles GT, Galloway JM, Vermaire JC, Crann CA, Falck H (2018) Late Holocene climatic variability in Subarctic Canada: insights from a high-resolution lake record from the central Northwest Territories. PLoS One 13(6):e0199872. https://doi.org/10.1371/journ al.pone.0199872

23. Gregory BR, Reinhardt EG, Macumber AL, Nasser NA, Patterson RT, Kovacs SE, Galloway JM (2017) Sequential sample reservoirs for Itrax-XRF analysis of discrete samples. J Paleolimnol 57:287-293

24. Gregory BR, Patterson RT, Reinhardt EG, Galloway JM, Roe HM (2019) An evaluation of methodologies for calibrating Itrax X-ray fluorescence counts with ICP-MS concentration data for discrete sediment samples. Chem Geol 521:12-27

25. Löwemark L, Bloemsma M, Croudace I, Daly JS, Edwards RJ, Francus P, Galloway JM, Gregory BRB, Steven Huang J-J, Jones AF, Kylander M, Löwemark L, Luo Y, Maclachlan S, Ohlendorf C, Patterson RT, Pearce C, Profe J, Reinhardt EG, Stranne C, Tjallingii R, Turner JN (2019) Practical guidelines and recent advances in the Itrax XRF core-scanning procedure. Quat Int 514:16-29. https:// doi.org/10.1016/j.quaint.2018.10.044

26. LoDico JM, Flower BP, Quinn TM (2006) Subcentennial-scale climatic and hydrologic variability in the Gulf of Mexico during the early Holocene. Paleoceanogr Paleoclimatol 21:PA3015. https:// doi.org/10.1029/2005PA001243

27. Boës X, Rydberg J, Martinez-Cortizas A, Bindler R, Renberg I (2011) Evaluation of conservative lithogenic elements ( $\mathrm{Ti}, \mathrm{Zr}$, $\mathrm{Al}$, and $\mathrm{Rb}$ ) to study anthropogenic element enrichments in lake sediments. J Paleolimnol 46:75-87

28. Cockburn CF, Gregory RB, Nasser NA, Patterson RT (2020) Intralake Arcellinida (testate lobose amoebae) response to winter de-icing contamination in an eastern Canada road-side 'Salt Belt' lake. Microb Ecol. https://doi.org/10.1007/s00248-020-01513-w

29. McNeill-Jewer CA, Reinhardt EG, Collins S, Kovacs S, Chan WM, Devos F, LeMaillot CL (2019) The effect of seasonal rainfall on nutrient input and biological productivity in the Yax Chen cave system (Ox Bel Ha), Mexico, and implications for $\mu$ XRF core studies of paleohydrology. Palaeogeogr Palaeoclimatol Palaeoecol 534:109289. https://doi.org/10.1016/j.palaeo.2019.109289

30. Metcalfe SE, Jones MD, Davies SJ, Noren A, MacKenzie A (2010) Climate variability over the last two millennia in the North American Monsoon region, recorded in laminated lake sediments from Laguna de Juanacatlán, Mexico. Holocene 20:11951206. https://doi.org/10.1177/0959683610371994

31. Pajari GE (1973) The Harvey volcanic area. In: Rast N (ed) Geology of New Brunswick, field guide to excursions, New England Intercollegiate Geological Conference, Department of Geology, University of New Brunswick, Fredericton, New Brunswick, Trip A-14 and B-11, pp 119-123

32. Dostal J, van Hengstum TR, Shellnutt JG, Hanley JJ (2016) Petrogenetic evolution of Late Paleozoic rhyolites of the Harvey Group, southwestern New Brunswick (Canada) hosting uranium mineralization. Contrib Mineral Petrol 171:20. https:// doi.org/10.1007/s00410-016-1270-8

33. McKerrow WS, Ziegler AM (1971) The lower Silurian paleogeography of New Brunswick and adjacent areas. J Geol 79(6):635646. https://doi.org/10.1086/627695

34. Murray MR (2002) Is laser particle size determination possible for carbonate-rich lake sediments? J Paleolimnol 27:173-183

35. van Hengstum PJ, Reinhardt EG, Boyce Jl, Clark C (2007) Changing sedimentation patterns due to historical land-use change in Frenchman's Bay, Pickering, Canada: evidence from highresolution textural analysis. J Paleolimnol 37:603-618. https:// doi.org/10.1007/s10933-006-9057-y

36. Blott SJ, Pye K (2001) GRADISTAT: a grain size distribution and statistics package for the analysis of unconsolidated sediments. Earth Surf Process Landf 26:1237-1248

37. Gregory BR, Patterson RT, Reinhardt EG, Galloway JM, Roe HM (2018) Harvey Lake Itrax XRF-CS. Mendeley Data v1. https://doi. org/10.17632/3fpdwcgtcj.1

38. Sly PG (1978) Sedimentary processes in lakes. In: Lerman A (ed) Lakes: chemistry, geology, physics. Springer, New York, pp 65-89. https://doi.org/10.1007/978-1-4757-1152-3_3

39. Talley LD, Pickard GL, Emery WJ, Swift JH (2011) Descriptive physical oceanography: an introduction, 6th edn. Elsevier, p 564

40. Rasmussen JB, Rowan DJ (1997) Wave velocity thresholds for fine sediment accumulation in lakes, and their effect on zoobenthic biomass and composition. J N Am Benthol Soc 16:449-465

41. Smith IR, Sinclair IJ (1972) Deep water waves in lakes. Freshw Biol 2:387-399. https://doi.org/10.1111/j.1365-2427.1972.tb00378.x

42. Canada (2019a) Hourly data report for Fredericton A, New Brunswick [WWW Document]. https://climate.weather.gc. ca/climate_data/hourly_data_e.html?hlyRange=195301-01\%7C2010-04-08\&dlyRange =1951-04-01\%7C201 2-01-12\&mlyRange $=1951-01-01 \% 7 C 2008-01-01 \&$ Stati onID $=6157 \&$ Prov=NB\&urlExtension=_e.htmI\&searchType $=$ stnProv\&optLimit=yearRange \&Start Year $=1840 \&$ EndYe ar $=2019 \&$ selRowPerPage $=25 \&$ Line $=63 \&$ Month $=4 \&$ Day $=8 \& \mid \mathrm{stPr}$ ovince $=$ NB\&timeframe $=1 \&$ Year $=2010$. Accessed 10 Aug 2019

43. Canada (2019c) Beaufort wind scale table [WWW Document]. https://www.canada.ca/en/environment-climate-change/servi ces/general-marine-weather-information/understanding-forec asts/beaufort-wind-scale-table.html. Accessed 10 Aug 2019

44. Kido Y, Koshikawa T, Tada R (2006) Rapid and quantitative major element analysis method for wet fine-grained sediments using an XRF microscanner. Mar Geol 229:209-225

45. Boyle JF, Chiverrell RC, Schillereff D (2015) Approaches to water content correction and calibration for UXRF core scanning: comparing $X$-ray scattering with simple regression of elemental concentrations. In: Croudace IW, Rothwell RG (eds) Micro-XRF studies of sediment cores: applications of a non-destructive tool for environmental sciences. Springer, Dordrecht, pp 373-390

46. Chen Q, Kissel C, Govin A, Liu Z, Xie X (2016) Correction of interstitial water changes in calibration methods applied to XRF core-scanning major elements in long sediment cores: case study from the South China Sea. Geochem Geophys Geosyst 17:1-10

47. Shiode N, Shiode S (2011) Street-level spatial interpolation using network-based IDW and ordinary Kriging. Trans GIS 15:457-477. https://doi.org/10.1111/j.1467-9671.2011.01278.x

48. Karl JW, Maurer BA (2010) Spatial dependency of predictions from image segmentation: a variogram-based method to determine appropriate scales for producing land-management information. Ecol Inform 5:194-202

49. Panahi A, Cheng Q, Bonham-Carter GF (2004) Modelling lake sediment geochemical distribution using principal component, indicator kriging and multifractal power-spectrum analysis: a 
case study from Gowganda, Ontario. Geochem-Explor Env A 4:59-70. https://doi.org/10.1144/1467-7873/03-023

50. Menard E, Patterson RT, Nasser NA, Galloway JM, Falck H, Cott PA, Ellis $S$ (2019) Sub-bottom acoustic profiling as a cost-effective remediation assessment tool in toxic heavy metal contaminated lakes. SN Appl Sci 1:572. https://doi.org/10.1007/s4245 2-019-0588-Z

51. Wackernagel H (1995) Ordinary Kriging. In: Multivariate geostatistics. Springer, Berlin, Heidelberg, pp 74-81. https://doi. org/10.1007/978-3-662-03098-1_11

52. Canada (2019b) Topographic information [WWW Document]. Natural Resources Canada. https://www.nrcan.gc.ca/scienceand-data/science-and-research/earth-sciences/geography/ topographic-information/10785. Accessed 10 Aug 2019

53. Team, R.C. (2013) R: a language and environment for statistical computing. Online: https://www.r-project.org/. Accessed Jul 2020

54. Macumber AL (2019) Source code for wind frequency calculation, end member mixing analysis and correlogram. [WWW Document]. Github. https://github.com/AMacumber/Mazze Ila_HarveyLake. Accessed 10 Aug 2019

55. Gilbert R (1999) Calculated wave base in relation to the observed patterns of sediment deposition in northeastern Lake Ontario. J Great Lakes Res 25:883-891

56. Evans RD (1994) Empirical evidence of the importance of sediment resuspension in lakes. Hydrobiologia 284:5-12

57. Swindles GT, Galloway JM, Macumber AL, Croudace IW, Emery AR, Woulds C, Bateman MD, Parry L, Jones JM, Selby K, Rushby GT, Baird AJ, Woodroffe SA, Barlow NLM (2018) Sedimentary records of coastal storm surges: evidence of the 1953 North Sea event. Mar Geol 403:262-270. https://doi.org/10.1016/j.marge o.2018.06.013

58. Middleton GV (1976) Hydraulic interpretation of sand size distributions. J Geol 84:405-426

59. Sun D, Bloemendal J, Rea DK, Vandenberghe J, Jiang F, An Z, Su R (2002) Grain-size distribution function of polymodal sediments in hydraulic and aeolian environments, and numerical partitioning of the sedimentary components. Sediment Geol 152:263-277. https://doi.org/10.1016/S0037-0738(02)00082-9

60. Xiao J, Chang Z, Fan J, Zhou L, Zhai D, Wen R, Qin X (2012) The link between grain-size components and depositional processes in a modern clastic lake. Sedimentology 59:1050-1062. https:// doi.org/10.1111/j.1365-3091.2011.01294.x

61. Bailey AW (1955) Railways in New Brunswick. Unpublished MA Theses, University of New Brunswick

62. Croudace IW, Rothwell RG (2015) Micro-XRF studies of sediment cores: applications of a non-destructive tool for the environmental sciences. Springer

63. Egemose S, Reitzel K, Andersen FØ, Jensen HS (2013) Resuspension-mediated aluminium and phosphorus distribution in lake sediments after aluminium treatment. Hydrobiologia 701:79-88

64. Bengtsson L, Hellström T, Rakoczi L (1990) Redistribution of sediments in three Swedish lakes. Hydrobiologia 192:167-181

65. Donnelly JP, Woodruff JD (2007) Intense hurricane activity over the past 5,000 years controlled by El Niño and the West African monsoon. Nature 447:465

66. Toomey MR, Curry WB, Donnelly JP, van Hengstum PJ (2013) Reconstructing 7000 years of North Atlantic hurricane variability using deep-sea sediment cores from the western Great Bahama Bank. Paleoceanography 28:31-41. https://doi.org/10.1002/ palo.20012

67. Boës X, Fagel N (2008) Relationships between southern Chilean varved lake sediments, precipitation and ENSO for the last 600 years. J Paleolimnol 39:237-252

68. Ólafsdóttir KB, Geirsdóttir Á, Miller GH, Larsen DJ (2013) Evolution of NAO and AMO strength and cyclicity derived from a 3-ka varve-thickness record from Iceland. Quat Sci Rev 69:142-154. https://doi.org/10.1016/j.quascirev.2013.03.009

Publisher's Note Springer Nature remains neutral with regard to jurisdictional claims in published maps and institutional affiliations. 